\title{
Physical Properties and Environmental Impact of Mine Waste Resulting from the Exploitation of Gold in Bétaré-Oya, Central Africa
}

\author{
Kenfack Jean Victor*, Kagou Dongmo Armand, Tassongwa Bernard, Mbog Michel Bertrand, Miafo Nkeumo Pierre \\ Romaric
}

Department of Earth Science, Faculty of Science, University of Dschang, Dschang, Cameroon

Corresponding Author Email: victor.kenfack@univ-dschang.org

https://doi.org/10.18280/eesrj.070204

Received: 27 February 2020

Accepted: 22 May 2020

\section{Keywords:}

Bétaré-Oya, mine waste, environmental impact, civil engineering, physical properties

\begin{abstract}
Mine wastes cause a lot of environmental problems of which seriousness depend on their polluting potential, management method, physical stability of the containment infrastructures and specific climatic conditions of the storage site. In this context, several studies have been undertaken to develop new techniques that would allow effective and sustainable management of these mine waste. The present study carried out in BétaréOya locality deals with the management of mine waste, their physical properties and their potential use in buildings and public works. These wastes are constituted of pebbles, gravel, coarse sand, fine sand and unanalyzed materials, but are poorly graded for certain sites and well graded for others. The sand fraction contained in these wastes, if we stick to their sand equivalents ranging from 88.15 to 95.2 , translate very clean sand with almost total absence of fine clay. These mine wastes can be used to manufacture concrete with a poor plasticity which can be improved. The apparent density ranging from 1.665 to 1.778 and the specific weight from 2.670 to 2.751 determined show that the latter are less spoilable and denser, ideal for civil engineering works. According to the environmental requirements in force, these wastes pose almost no potential risk for constructions since there is no risk of AMD (Acidic Mine Drainage) related to sulfur. In addition, this upgrading approach makes it possible to reduce the quantities of mining wastes and thus their environmental impact while preserving non-renewable natural resources (clays, sand) intensively used in construction.
\end{abstract}

\section{INTRODUCTION}

The African continent has significant mineral resources, which represent about $30 \%$ of proven world reserves. It is full of metals such as platinum (89\%), chromium (81\%), manganese $(61 \%)$, bauxite $(30 \%)$ and gold $(40 \%)$. Their production compared to the world production is estimated at $50 \%$ for diamond, $15 \%$ for bauxite, $25 \%$ for gold, $20 \%$ for uranium, etc. The contribution of mining in Africa sometimes reaches $50 \%$ of Gross Domestic Product (GDP) for some countries [1]. The mining sector also helps to diversify economic and industrial activities; and is a source of income and job opportunities for many states. Given the diversity of actors involved and the importance of the resulting goods and services, the benefits of mining in Africa are important for the global economy. Unfortunately, Africa is still the poorest continent [1]. The African continent is in the heart of an unprecedented dynamic. With an average annual growth rate of $5 \%$ over the last decade, Africa is becoming an increasingly important player in the global economy. By 2050, Africa will have 1.5 billion inhabitants, $50 \%$ of whom will be urban [2]. This dynamism is accompanied by major challenges to improve the living conditions of the populations and to develop the economy of Africa. The challenge of housing and infrastructure is one of these major challenges. Eco-building materials such as laterite, limestone, vegetable fibers lowcarbon cements, new building materials based on recycled plastic waste or mining waste, just to name a few examples, represent one of the best ways to solve these challenges following sustainable development logic. They reduce greenhouse gas emissions, limit energy consumption and optimize the use of non-renewable natural resources. Moreover, by offering professionals efficient and economically viable technical solutions, eco-materials represent a real under exploited potential for the green growth on the continent.

The potential of mineral resources is enormous in Cameroon. Thus, by 2020, Cameroon will proceed to: The exploitation and transformation of mining deposits such as cobalt, nickel and manganese near Lomié estimated at more than 54 million tons of ores; M'balam iron deposit averaging 2.5 billion tons with $40 \%$ iron and Kribi estimated at 350 million tons with $35 \%$ iron; N'gaoundal and Mini-Martap bauxite estimated at more than 1 billion tonnes with $43 \% \mathrm{AlO}_{3}$; the Akonolinga Rutile with geological reserves of about 300 million tonnes with $0.9 \% \mathrm{TiO}_{2} ;$ Mobilong diamond with reserves estimated at more than 700 million carats [3].

Mining Code, promulgated in Cameroon in 2001 and amended in 2010 aims on one hand, to govern the mining activities and promote investments in the mining sector in Cameroon and, on the other hand to promote and encourage the research and exploitation of the mineral resources necessary for the economic and social development of the country as well as the fight against poverty. Almost all the investments of the national or multinational mining companies working in Cameroon target base metals $(\mathrm{Cu}, \mathrm{Co}, \mathrm{Sn})$ and 
precious mineral substances (gold, diamond, ...). Exploitation of these mineral substances has a negative impact due to products released into the environment. The wastes produced by industries are often poorly integrated into the landscape and the restoration of the degraded site is often long and expensive. In such situation, the Cameroonian public authorities insist on preserving the environment, which is in line with the Sustainable Development Goals (SDGs).

The development of the mining sector in Cameroon especially in the locality of Bétaré-Oya presents biophysical and environmental consequences. Indeed, the actual exploitation techniques cause important damages on the populations and the ecosystems. These damages include: soil degradation and loss of biodiversity, pollution of surface and underground waters, destruction of natural habitats, atmospheric pollution, social conflicts, and relocation of communities, sociocultural and economic upheaval, and other undesirable health effects. The better management of this mining sector will allow an increase in the added value of mine waste in order to find reliable solutions for their reuse as raw materials in civil engineering.

With the population growth, the Central African crisis and the high costs of building materials, the East Region of Cameroon is facing serious housing problems whereas housing is a fundamental element of people's physical, psychological, social and economic well-being. The locality of Bétaré-Oya in this region is known for its strong gold potential causing a massive rush for this ore. Mining in the area has resulted in demographic growth, which causes a serious accommodation problem. With regard to this difficulty encountered in the region, it is necessary for mining companies to valorize the mine waste products in civil engineering in order to overcome the housing problem and sustainable mining activity.
In the light of the damage resulting from mining, it is questionable whether the use of these wastes as alternative raw material in building materials is a promising environmental solution.

This work as well as the study and surveys conducted by Tchindjang et al. [4] throughout Lom and Djérem constitute a kind of environmental inspection combined with these factual assessments and real impacts of all kinds. Although the works of ref. [4] focus as much on employment and income (poverty), forest management, biodiversity management and conservation, with some shortcomings on both the economic and the ecological aspects and the issue of mining waste poorly addressed. In order to compensate for these shortcomings, the present work which is not only aim at reducing mining waste volumes which present a potential risk for the environment, but also at preserving the non-renewable natural resources (clays, sands, gravel) intensively used in construction. It aims to add value to wastes in order to find reliable solutions for their reuse as secondary raw materials in civil engineering [5]. The challenges of reusing the mining waste are numerous. Two major challenges can be distinguished: the first is related to the societal acceptability of the idea to use mining waste and the second is mainly related to the technical challenges. Thus, a potential investment following promising results could be a potential source of business creation with raw materials for these mining wastes. This would create jobs and sustainable development in the locality of Bétaré-Oya.

\section{STUDY AREA AND GEOLOGICAL SETTING}

The study area situated at Bétare-Oya extends between the longitude $14^{\circ} 05$ 'and $14^{\circ} 10^{\prime} \mathrm{E}$ and latitude $5^{\circ} 35^{\prime}$ and $5^{\circ} 40^{\prime} \mathrm{N}$.
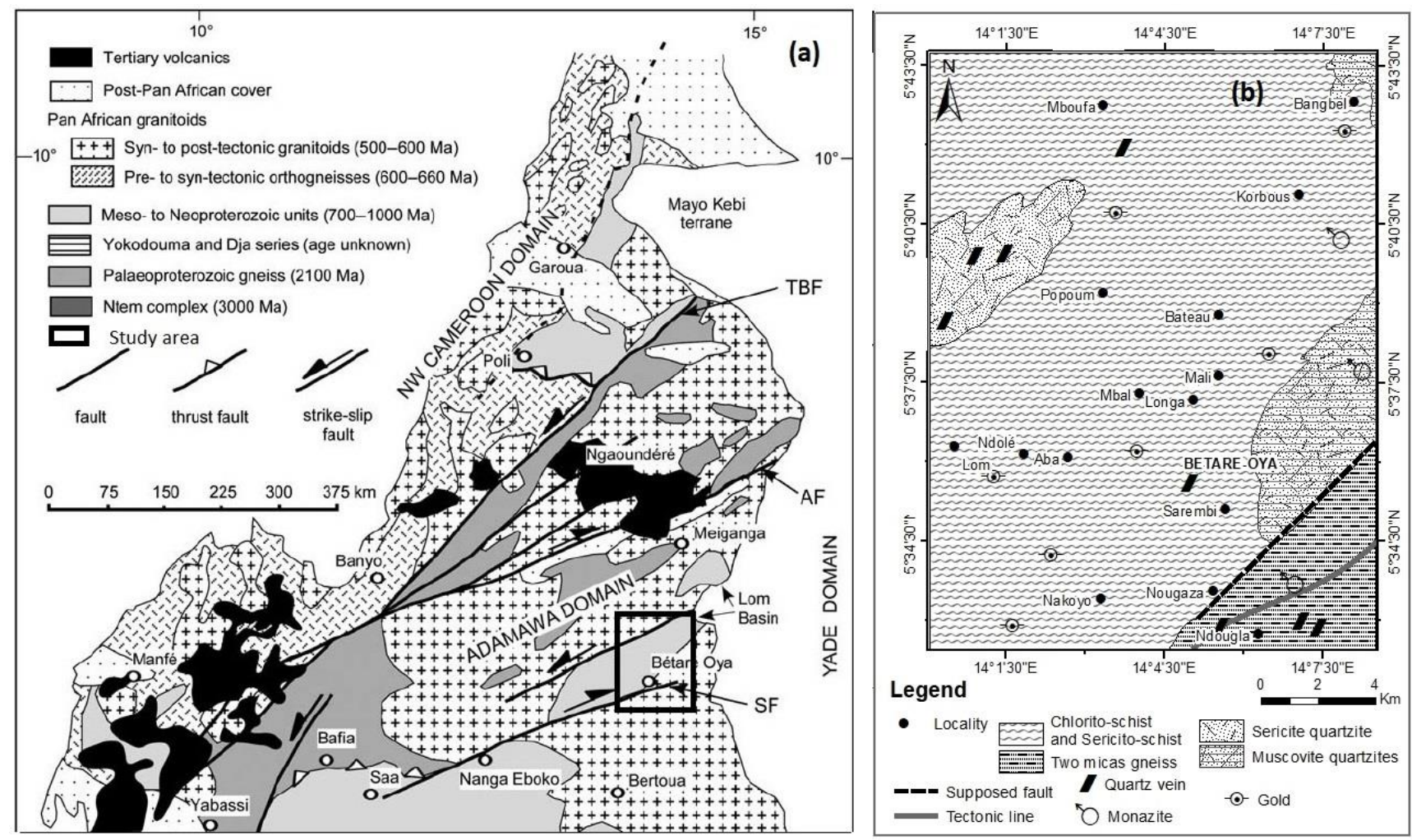

Figure 1. Geological maps of the study area. a) Geological map of Cameroon showing major lithotectonic suites and domains. Modified from [6]. AF, Adamawa fault; KCF, Kribi- Campo fault; SF, Sanaga fault; TBF, Tchollir ' -Banyo fault; b). Detail of the geological map of the Bétaré-Oya area [7-9] 
The Bétaré-Oya locality belongs to the Pan-African basement of central Cameroon, which is bordered on the north and south by two large-scale shear zones: the Adamaoua shear zones and Sanaga fault respectively (Figure 1a). The location of the study area in Central-East Cameroon is shown in Figure 1. The Lom series is structurally subdivided into two broad areas [10]. Domain I consists of ancient rocks (gneiss and migmatites) and domain II consisting of recent rocks (metavolcano-sedimentary rocks: mylonites, quartzites, micaschists, meta-sediments and meta-volcanites). The two are separated by the Bétaré-Oya NE-SW shear zone. The geological map of the Bétaré-Oya zone [7-9] shows lithological units and structural data of the terrain (Figure 1b).

This area belongs to the series of Lom which forms with the series of Poli, Mbalmayo-Bengbis, and Yokadouma the intermediate series of the Central African Mobile Zone of Panafrican age [11]. The Lom series corresponds to a narrow and discontinuous belt, oriented NE-SW and consisting of a lower unit and an upper unit [12]. The Lom series, or schistoquarzitic series, covers an area of about $2,000 \mathrm{~km}^{2}$ in central-eastern Cameroon and continues in the Central African Republic. Geologically, it is essentially schistoquartzitic with clear volcanosedimentary footprints, and has undergone a mesozonal regional metamorphism and locally a thermal metamorphism related to magmatic intrusions [13]. Gold is in the schistoquartzitic series of Lom. In this series, primary gold appears to be associated with diffuse and ubiquitous quartz vein, apparently consistent with schistosity. This gold is also associated with tectonic sheared zones, with oblique and subvertical veins (Figure 1b).

\section{METHOD}

\subsection{Fieldwork}

Numerous data was collected in the study area to identify the different morpho-landscape and lithological domains in order to select the best sites for sample collection. This involved interviewing the actors of mining crafts, oblique photographs, site visits, location and GPS positioning of the various mining sites. The environmental impacts vary considerably according to several specific factors to the mine sites, such as the location and topography of the deposit, the nature of the surrounding environment, the nature and type of deposit, the tools and methods used for mining and the extraction of materials, the location of the deposit in relation to the socio-economic reflection, etc. The present study is based on ref. [14] for the identification and characterization of environmental impacts and ref. [15] for the evaluation of environmental impacts.

Material samples were collected at four mine sites in the locality (Figure 2) and laboratory studies were performed to determine their physical properties. The analyzed samples were taken from piles of granular materials stored in sites after gold mining. When a granular material is put in stock, the large elements tend to roll down the pile while particles with smaller diameter remain at the top. The removal of material at the top, middle, bottom and inside of the pile of aggregates permitted us to have a representative sample. These various fractions were carefully mixed.

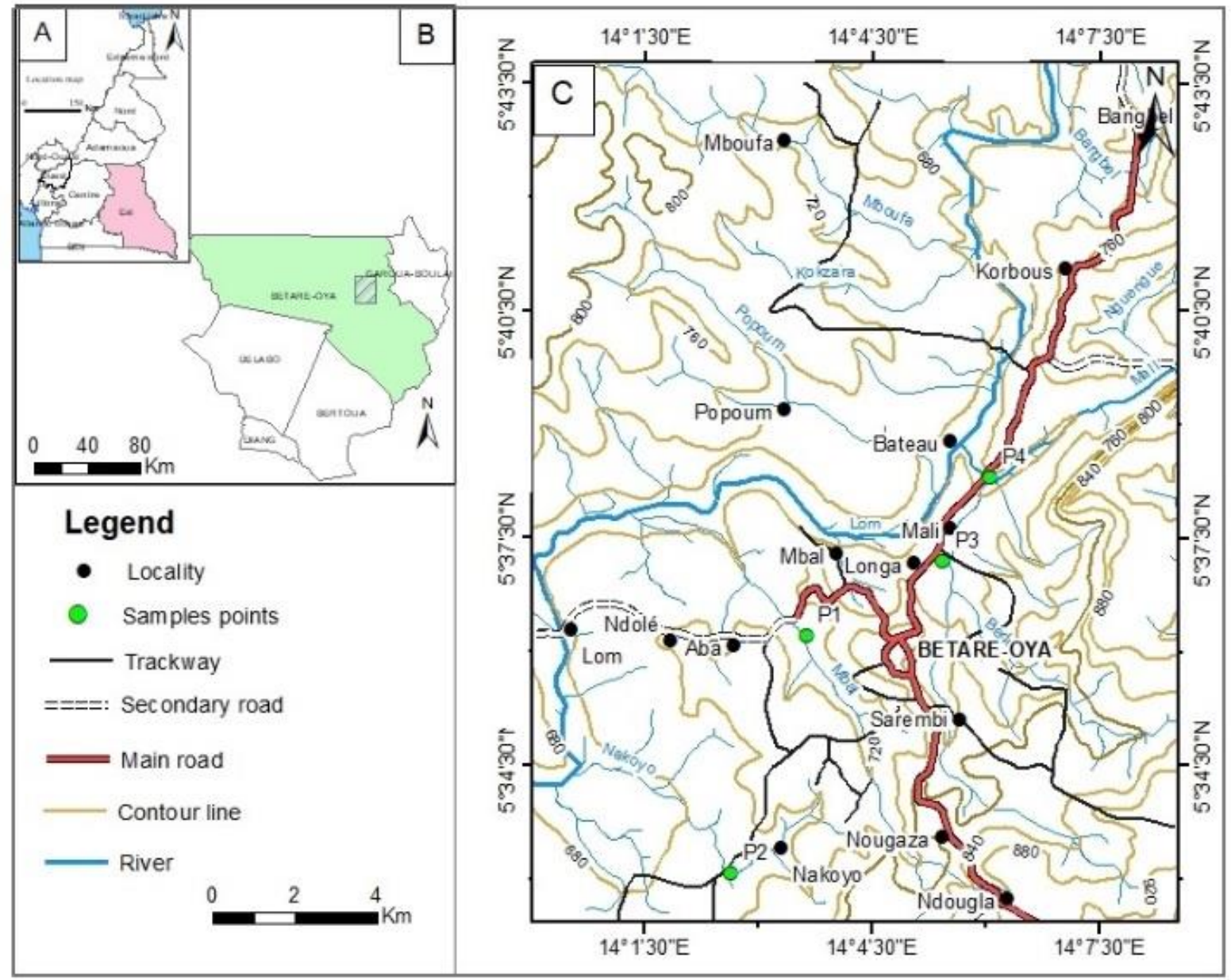

Figure 2. Topographic map showing the sampling points 


\subsection{Laboratory tests}

Bulk density, specific weight, sand equivalent, particle size distribution and fineness module were performed. The apparent density is determined by the mold method according to standard [16]. The test consists of successively measuring the mass $(\mathrm{m})$ and volume (v) parameters that characterize the same soil sample of density $\rho$.

$$
\rho=\frac{m}{V}
$$

The specific gravity of the particles is determined by using the pycnometer according to the French standard [17]. The test consists of measuring the intrinsic volume of grains excluding voids and calculating the ratio between their weights and their volumes. It applies to all intact or reworked soil samples of which the size of the largest particles is less than $2 \mathrm{~mm}$. The wet $\gamma_{h}$ and dry $\gamma_{d}$ specific weights are successively determined by Eqns. (2) and (3):

$$
\begin{gathered}
\gamma_{h}=\frac{P_{1}}{V} \\
\gamma_{d}=\frac{\gamma_{h}}{1+w}
\end{gathered}
$$

where, the volume $V$ of the sample is calculated from Eq. (4):

$$
V=\frac{P_{2}-P_{3}}{\gamma_{w}}-\frac{P_{2}-P_{1}}{\gamma_{p}}
$$

where, $\gamma_{p}$ is the density of paraffin $\left(0.9 \mathrm{~g} / \mathrm{cm}^{3}\right) ; P_{l}$ the wet weight of the sample; $\gamma_{w}$ the density of the water at the temperature of the test; $P_{2}$ the weight of the paraffin covered sample; $P_{3}$ the weight of the submerged sample; $w$ : water content of the sample.

Particle size distribution is then used to calculate the particle size parameters (Curvature coefficient, Uniformity coefficient, Fineness module) of the samples. The particle size distribution was performed according to ref. [18] standard. The analysis consists of separating and classifying these different grains according to their diameters using a sieve, nested on each other, with mesh size decreasing from top to bottom. The studied sample is put on the upper sieve and the classification of the grains is obtained by vibrating the sieve column or by manual shaking.

The percentages of the Cumulative Retains (CR) and the percentages of the passing $(\mathrm{CP})$ are calculated respectively using Eqns. (5) and (6):

$$
\begin{gathered}
C R=\frac{R}{W} .100 \\
C P=100-(R C)
\end{gathered}
$$

where, $R$ is the weight of refusal and $W$ the total weight of the sample.

The particle size curve is then plotted on a standardized format, with the dimensions of the sieve openings or the sieve modules on the $\mathrm{x}$-axis and the percentage of passing (or retains) on the y-axis. The grain size of a soil can be characterized by:
(1) The coefficient of uniformity $C u$ which express the spread of the granulometric curve.

$$
C u=\frac{D_{60}}{D_{10}}
$$

where, $D_{60}$ is the effective particle diameter corresponding to $60 \%$ of the pass and $D_{10}$ is the effective particle diameter corresponding to $10 \%$ of the pass; (2) The curvature coefficient $C c$ for describing the shape of the grain size curve is expressed by Eq. (8):

$$
C c=\frac{\left(D_{30}\right)^{2}}{D_{10} \cdot D_{60}}
$$

where, $D_{30}$ is the effective particle diameter which corresponds to $30 \%$ of passing.

The equivalent of sand is determined by washing according to ref. [19] standard. This test is used to evaluate the cleanliness of sand for concrete. The test consists of separating the fine particles contained in the soil from coarser sand elements. The test is carried out on the $0 / 5 \mathrm{~mm}$ fraction of the material to be studied. The sieving is done when the material is wet so as not to lose fine elements. The sample is washed according to a standardized process. After 20 minutes, measure the height $h_{l}$ of the sand and fine elements; the height $h_{2}$ of the clean sand only and we deduce the equivalent of sand which is conventionally given by the Eq. (9):

$$
E S=\frac{h_{2}}{h_{1}} \cdot 100
$$

Depending on whether the height $h_{2}$ is presented visually or with a piston, VSE (Visual Sand Equivalent) or SE (Sand Equivalent to the piston) are determined.

\section{RESULTS}

\subsection{Mining wastes}

Gold mining generates a variety of wastes [20] such as: (1) gangue rock consisting of dead lands or lateritic ferralitic soils that have been removed to provide access to the mineralized layer (2) gangue rock fragments of metamorphic nature such as shale, chlorite-schists representing the non-valuable part of the extracted rock (case of primary deposit) or mineralized layer (case of alluvial deposit); (3) Residues consisting leached gravel, sand, silt, water and sometimes chemical additives like mercury used during the ore processing; (4) Sludge consisting of very fine particles of silt and clay.

\subsection{Impacts of mining wastes on the environment}

The study area is subjected to semi-mechanized artisanal mining. The impact is significant in the especially in the goldrich Lom zones where vast areas are being disturbed. At all mining sites, vegetation cover has almost disappeared and no reforestation measures are being implemented (Figure 3a, b).

The washing of the ore requires a large amount of water. The provision of the latter involves the diversion of watercourses and the creation of reservoir. However, they strongly modify the water balance of the region and reinforce 
conflicts due to the use of the resource. Some rivers eventually dry up, resulting in the disappearance of local fauna and flora. The bed and banks are dotted with potholes and ditches (Figure 3c, d), creating stagnant water, which serve as a breeding ground for mosquitoes, schistosomiasis and other waterborne diseases. In addition the silting of rivers is a direct consequence. The water used to wash the ore is discharged directly into the natural environment without any treatment. This rejected water is highly charged with suspended matter and increases the turbidity of the streams (Figure 3e, f). The use of a settling basin is not applicable in Bétaré-Oya. Thus the sediment load is too high with an effect on aquatic life and reduces light and nutrition mechanism by filtration. Mechanical pumping results in the pollution of the river, the disturbing noise of the water pumps, and the micro-pollution caused by the engine oil and gasoline from the fuel pumps.

With regard to soils, the material (sterile) extracted from the potholes is piled up and forms mounts and hills (Figure $3 a, b$, $\mathrm{g}, \mathrm{h}$ ), with environmental impacts such as local modification of the external geodynamic processes (erosion, sedimentation, etc.); local modification of the superficial geochemistry of soil with superposition of soil horizons $\mathrm{C}$, on soil horizons A which are favourable for agriculture; the pressure of the load on the ground present a high risk of slope instability which can lead to landslides.

The excavation of wells and pits and the accumulation of waste in the long run could alter the topography. In BétaréOya, no actor involved in the mechanization of the mining industry has set up a process to limit soil degradation, no prior removal of humus before quarrying, no Planting of trees to facilitate the regeneration of soil and vegetation cover.

The disposal of solid waste from the further mechanization of gold mining creates solid waste that destroys and delays the growth of vegetation. Soils stirred by digging will be delivered to leaching and degradation. Waste rock and ore will be dumped into streams and clogged. Fortunately, there is no use of chemicals for the treatment of gold (mercury and cyanide).
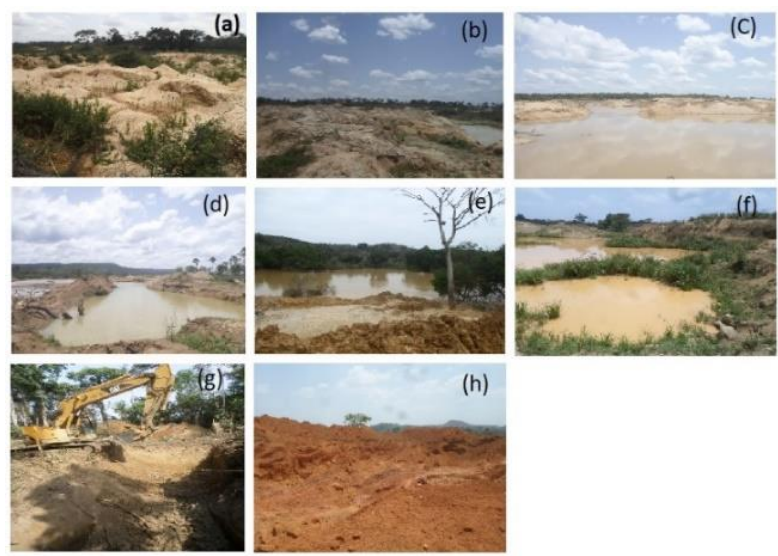

(h)
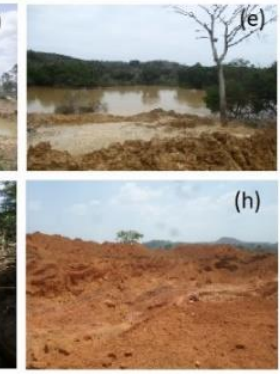

Figure 3. Mining waste impact photography a) Diminution of topsoil, b) Disfigurement of the landscape, c) Silting of the

river Lom, d) Change of the drainage bed system, e)

Pollution of surface water, f) Increase in turbidity, g) Digging Phase, h) Piles of cuttings

The impact of mine tailings on air results from the detrimental effects of grinding minerals that produce noise and silica-rich dust. Miners are thus exposed to this silica dust that sooner or later would cause silicosis especially in women and children.

The observation made in the field shows that the increase in mechanization of mining craftsmanship in Bétaré-Oya creates serious environmental and ecological consequences (Table 1). There is a significant impact on wildlife, flora, streams, soil, air, and many other components during the life phase of bringing into the area.

Table 1. Impact on the different environmental components

\begin{tabular}{|c|c|c|c|c|c|c|c|c|c|c|c|c|}
\hline 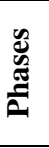 & $\begin{array}{c}\text { Main sources of } \\
\text { impact }\end{array}$ & Air & Water & Soil & Fauna & Flora & $\begin{array}{l}\text { Health } \\
\text { and } \\
\text { safety }\end{array}$ & Landscape & Job & $\begin{array}{c}\text { Living } \\
\text { environment } \\
\text { and quality of } \\
\text { live }\end{array}$ & $\begin{array}{l}\text { Cultural } \\
\text { heritage }\end{array}$ & $\begin{array}{l}\text { Social } \\
\text { peace }\end{array}$ \\
\hline \multirow{9}{*}{ 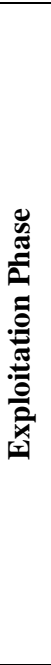 } & $\begin{array}{c}\text { Topsoil moving } \\
\text { with shovels } \\
\text { excavators }\end{array}$ & $*$ & $*$ & $*$ & $*$ & $*$ & $*$ & $*$ & & & $*$ & $*$ \\
\hline & Ore extraction & $*$ & $*$ & & $*$ & & $*$ & & & & & \\
\hline & $\begin{array}{l}\text { Movement of the } \\
\text { gears }\end{array}$ & $*$ & & $*$ & $*$ & & $*$ & & & & & $*$ \\
\hline & $\begin{array}{l}\text { Storage of } \\
\text { products }\end{array}$ & & & $*$ & & & & & & & & \\
\hline & $\begin{array}{c}\text { Manipulation of } \\
\text { oil and gas }\end{array}$ & $*$ & $*$ & $*$ & & & & & & & & \\
\hline & $\begin{array}{c}\text { Unloading of } \\
\text { tanks }\end{array}$ & $*$ & & & & & $*$ & & & & & $*$ \\
\hline & $\begin{array}{c}\text { Mechanical } \\
\text { work on the site }\end{array}$ & $*$ & & & $*$ & & $*$ & & & & & \\
\hline & $\begin{array}{l}\text { Deviation from } \\
\text { the bed of the } \\
\text { watercourse }\end{array}$ & & $*$ & $*$ & & $*$ & * & & & & & \\
\hline & Ore washing & $*$ & $*$ & & & & $*$ & & $*$ & & & $*$ \\
\hline \multirow{3}{*}{$\stackrel{0}{\stackrel{0}{0}}$} & Stop activities & & & & & & & & $*$ & $*$ & & \\
\hline & $\begin{array}{l}\text { Demolition of } \\
\text { the facilities }\end{array}$ & $*$ & & $*$ & $*$ & & & $*$ & & & & $*$ \\
\hline & $\begin{array}{l}\text { Rehabilitation of } \\
\text { the sites }\end{array}$ & $*$ & & $*$ & & $*$ & * & $*$ & * & $*$ & * & \\
\hline
\end{tabular}

Note: *represents the component of the environment where each phase has a visible and identifiable impact 


\subsection{Physical characterization}

The particle size analysis (Figure 4) provides information on the main particle size parameters of the samples, namely the HAZEN coefficient and the curvature coefficient; the fineness module of different samples and the composition of particle. It follows that samples $\mathrm{P}_{1}, \mathrm{P}_{2}$ and $\mathrm{P}_{3}$ have a uniformity coefficient of $186.6,18.6,17.5$ respectively and a curvature coefficient of 5.95, 0.148 and 0.142 . The finess module of the samples $\mathrm{P}_{1}, \mathrm{P}_{2}, \mathrm{P}_{3}$ and $\mathrm{P}_{4}$ are respectively $3.57 ; 3.55 ; 3.61$ and 2.7. The materials consist of various pebbles, gravel, coarse sands, fine sands and other materials represented in the form of traces.

The granular composition (Table 2) has a percentage of pebbles less than or equal to $1 \%$; a gravel percentage varying between $36.2 \%$ and $49.2 \%$; a percentage of coarse sand ranging between $27.8 \%$ and $41.6 \%$; that of fine sand between $4.6 \%$ and $9.2 \%$ and a percentage of non-analyzed materials varying between $4.8 \%$ and $6 \%$ for Samples $\mathrm{P}_{1}, \mathrm{P}_{2}$ and $\mathrm{P}_{3}$ and $31.4 \%$ for Sample $\mathrm{P}_{4}$. It appears that the materials resulting from the mining wastes is constituted of gravel (36-49\%) and coarse sand $(28-42 \%)$.

Samples $\mathrm{P}_{1}, \mathrm{P}_{2}, \mathrm{P}_{3}$ and $\mathrm{P}_{4}$ respectively have a visual sand equivalent of 95.6, 95.9, 92.6 and 92.7 and the piston sand equivalent of $90.3,91.2,88.15,95.2$ (Table 3). The apparent densities vary from $1.665\left(\right.$ Sample $\mathrm{P}_{3}$ ) to 1.778 (Samples $\mathrm{P}_{1}$ and $\mathrm{P}_{4}$ ). The specific weights vary between $2.670 \mathrm{t} / \mathrm{m}^{3}$ (Sample $\mathrm{P}_{1}$ and $\mathrm{P}_{4}$ ) and $2.75 \mathrm{t} / \mathrm{m}^{3}$ (Sample $\mathrm{P}_{2}$ ). Sample $\mathrm{P}_{3}$ having a specific weight of $2.72 \mathrm{t} / \mathrm{m}^{3}$.

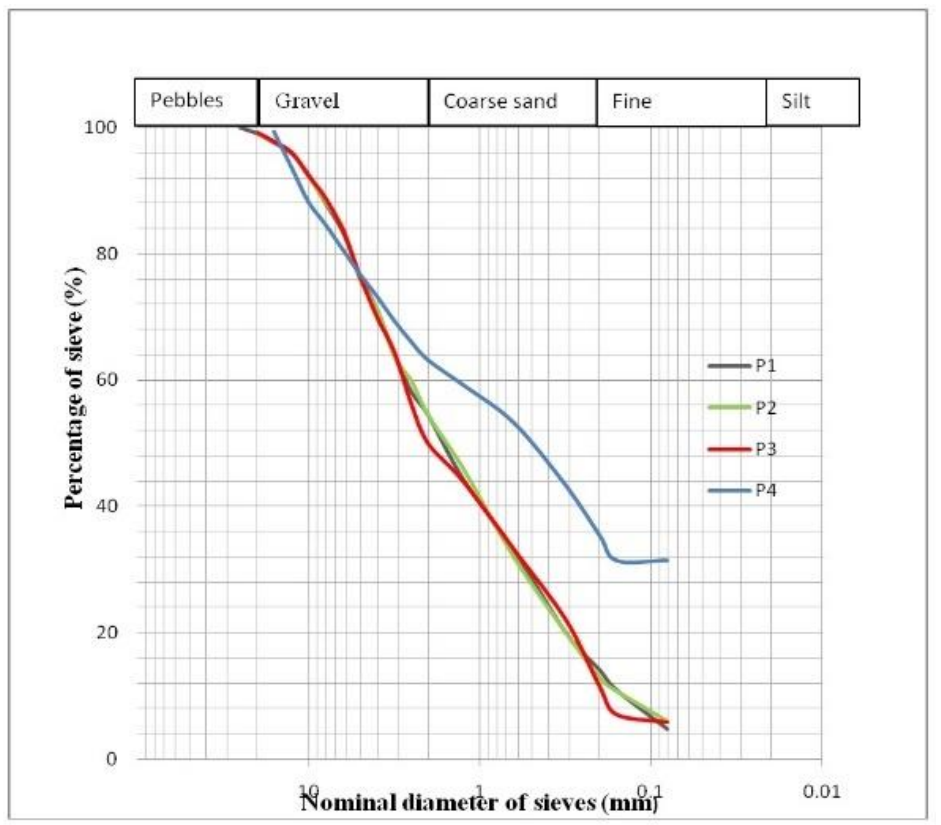

Figure 4. Grain size distribution curve of the different samples

Table 2. Summary of aggregate composition of different samples

\begin{tabular}{cccccc}
\hline Samples & Pebble (\%) & Gravel (\%) & Coarse sand (\%) & Fine sand (\%) & Non-analyzed materials $(\%)$ \\
\hline Sample $\mathbf{P}_{\mathbf{1}}$ & 1.0 & 44.6 & 40.4 & 9.2 & 4.8 \\
Sample $\mathbf{P}_{\mathbf{2}}$ & 1.0 & 44.6 & 41.6 & 6.8 & 6.0 \\
Sample $\mathbf{P}_{\mathbf{3}}$ & 0.8 & 49.2 & 38.6 & 5.6 & 5.8 \\
Sample $\mathbf{P}_{\mathbf{4}}$ & 0.0 & 36.2 & 27.8 & 4.6 & 31.4 \\
\hline
\end{tabular}

Table 3. Physical characterization

\begin{tabular}{|c|c|c|c|c|c|c|c|c|c|c|}
\hline$\frac{\tilde{E}}{\tilde{E}}$ & 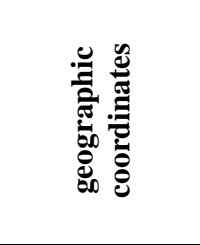 & 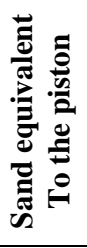 & 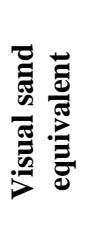 & 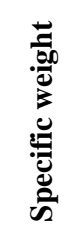 & 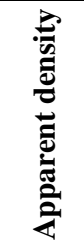 & 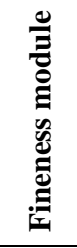 & 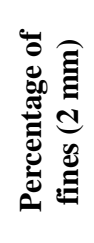 & 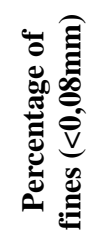 & 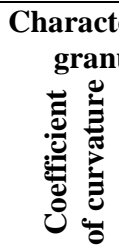 & $\begin{array}{l}\text { of the } \\
\text { try }\end{array}$ \\
\hline $\mathbf{P}_{1}$ & $\begin{array}{c}05^{\circ} 36^{\prime} 12.4{ }^{\prime \prime} \mathrm{N} \\
014^{\circ} 03{ }^{\prime} 38.07^{\prime}, \mathrm{E}\end{array}$ & 90.3 & 95.6 & 2.670 & 1.66 & 3.57 & $54.4 \%$ & $11 \%$ & 1.42 & 17.5 \\
\hline $\mathbf{P}_{2}$ & $\begin{array}{c}05^{\circ} 33^{\prime} 4.05^{\prime \prime} \mathrm{N} \\
014^{\circ} 02^{\prime} 38.77^{\prime} ' \mathrm{E}\end{array}$ & 91.2 & 95.9 & 2.751 & 1.778 & 3.55 & $54.4 \%$ & $10.8 \%$ & 5.95 & 186.6 \\
\hline $\mathbf{P}_{3}$ & $\begin{array}{c}05^{\circ} 38^{\prime} 18.52^{\prime \prime} \mathrm{N} \\
014^{\circ} 05^{\prime} 59.58^{\prime \prime} \mathrm{E}\end{array}$ & 88.15 & 92.6 & 2.726 & 1.686 & 3.61 & $50.0 \%$ & $10.8 \%$ & 0.148 & 18.6 \\
\hline $\mathbf{P}_{4}$ & $\begin{array}{l}05^{\circ} 38^{\prime} 18.52^{\prime \prime} \mathrm{N} \\
014^{\circ} 06^{\prime} 03.57^{\prime}, \mathrm{E}\end{array}$ & 95.2 & 92.7 & 2.670 & 1.727 & 2.7 & $63.2 \%$ & $14.25 \%$ & - & - \\
\hline & Minimum & 88.15 & 92.7 & 2.67 & 1.66 & 2.7 & $50.0 \%$ & $10.8 \%$ & 0.148 & 17.5 \\
\hline & Maximum & 95,2 & 95.9 & 2.75 & 1.727 & 3.61 & $63.2 \%$ & $14.2 \%$ & 5.95 & 186.6 \\
\hline & Moyenne & 91.21 & 94.2 & 2.704 & 1.712 & 3.3 & 55.50 & $11.7 \%$ & - & - \\
\hline
\end{tabular}




\section{DISCUSSION}

This work is part of an ecological and rational management of mining discharges taking into account the economic, technical and environmental constraints of waste. It joins the goal of ecological engineering that aims to break with the traditional linear approach of industrial activities that does not include the non-renewable nature of resources, nor the inability of these industries to absorb all the waste produced. Indeed, the work of ref. [21-25] as well as those of ref. [26] concerning the Boumba and Ngoko or Kadey Departments were focused on socio-economic impacts, aspects of the legal content of mining permits, tax obligations, income management and land disputes, but does not address the issue of ecological impacts. Ref. [27] solve into all their extent the question of the impacts of mining in the Congo Basin. They specify that "much of the discourse on conflict minerals rightly places emphasis on human rights concerns, unfortunately does not address the fact that it takes place in two of the most important ecosystems on the planet: the Congo Basin and the Albertine rift". Regarding the use of mine discharges, it should be noted that a long journey has to be made for the reuse of mining waste in construction, since every time we talk about mine discharges, we automatically think of risk instead of opportunity [28]. Secondly, the collection, transport, sorting and the necessity of pre-treatment of rejects are also major challenges because of the large volumes produced as all discharges are not always used. From a sustainable local development perspective, the present work has the advantage of contributing to the promotion of local building materials and encouraging the creation of small and medium-sized enterprises in the locality. The sand equivalent of Betaré-Oya materials ranging from 88.15 to 95.2 is much higher than that obtained by Taha [29] from the Toutsang sand pit in Dschang which is 38.80 for the sands.

It ranges from 17.66 to 76.10 , depending on whether they are in presence of red and white unwashed sands with values of $17.66 \%$ and $34.33 \%$ respectively, and depending on whether there are in presence of red and white washed sand, for respective values of $66.23 \%$ and $76.10 \%$ ) [30]. This high sand purity of in the Betaré-Oya locality could be related to the metamorphic nature (quartzites, shales, etc.) of the bedrock. The fineness module for sands ranging from 2.7 to 3.61 is lower than that obtained by Ngapgue [31] on the Batie sands (2.98 to 3.74). It is much higher than that obtained by Awona [32] on the Foulou River sand (2.61) in the Akak locality. This high rate of finess module in these wastes may be due to the gold mining technique since the mineralized layer is most often in contact with the source rock, hence the presence of coarse particles in the mineralized layer. The sand fraction is almost identical to that river Nkam [33] where sands are mostly coarse grained arenites [34]. In contrary, sands from Limbé beach are mainly fine grain arenites [35]. Sand is unavoidable and irreplacable in building industry. Most constructions in permanent materials integrate their uses. Thus, in the building sector, according to Bedard [36] classification, the sands resulting from gold mining discharges in the locality come in three broad granulometric classes each with a specific use: In the field of geotechnical engineering, sands ranging in size from $0.0625 \mathrm{~mm}$ to $0.465 \mathrm{~mm}$ can be used for patching (tiling adhesives), mortars and plaster coatings that protect the building from exterior attack and help to decorate the building; average sands ranging from $0.465 \mathrm{~mm}$ to $2 \mathrm{~mm}$ can be used for roughing, finishing, and breeze blocking, while coarse sands ranging in size from $2 \mathrm{~mm}$ to $4.75 \mathrm{~mm}$ can be used for the manufacture of concrete, and facades decoration work. They have the advantage of being less dangerous than the quarry sands that are the main cause of silicosis and lung cancer in building technicians. The gravel fraction is considerable in various samples and is most often involved in the structural work. The combination of gravel and coarse sands could be used to make reinforced concrete. The small proportion of the pebble fraction in the wastes could serve, after realizations of the Los Angeles and Micro Deval tests, to the decoration of buildings and the formulation of concretes. Since these discharges have a wide range of particle sizes ranging from pebbles to fine sands, they should be separated beforehand from a double sieving because the first sieving will separate pebbles, ideal for decorations. The second sieve will provide coarse sands for the confession of concrete and fine sands which are ideal for plaster and mortar for joint and topcoats.

\section{CONCLUSION}

The aim of this study was to characterize mining waste from semi-mechanized artisanal gold mining in Betaré-Oya locality. The work presented is part of the general problem of sustainable development, improvement and mastery of the properties of building materials. Because of the economic importance of these mining discharges and the fundamental aspect involved in their study, research is directed to the conservation of industrial and scientific interests. This study shows that the exploitation of gold generates numerous products that are, among other, stripping and mining waste rock (gravel, sand) and processing residues (pulp). Without strong actions in favour of responsible mining, this mining waste can cause a considerable impact on the environment such as soil degradation and the loss of biodiversity, pollution of surface and underground water, destruction of natural habitats, air pollution, relocation of communities and undesirable health effects, safety and well-being of populations and workers. Laboratory tests show that sand equivalent ranged from 88.15 to 95.2 with an average of 91.21. This average value which is more than the values recommended for the equivalent of sand by Dreux [37] (PS> 80) makes it possible to affirm that these sands are very clean with almost total absence of fine clay but risk of causing a lack of plasticity of the concrete. This can be corrected by increasing the water amount. The percentages of the fines are generally between $10.8 \%$ and $14.25 \%$ with an average of $11.7 \%$ and influence the mechanical behaviour of these materials. The fineness module between 2.7 and 3.6 with an average of 3.3 is the factor limiting the use of the large proportion of these materials under construction subject to improvement by adding fine sand.

\section{ACKNOWLEDGMENT}

We thank the laboratory of Earth and Environmental Sciences of the University of Dschang to initiate this study.

\section{REFERENCES}

[1] Awono Atangana, J.M. (2012). Gestion durable de 1'exploitation minière au Cameroun : cas de la petite 
mine d'or à Betare-oya (est du Cameroun). Mémoire de Master spÉcialisé en Gestion Durable des Mines, 2iE, 60.

[2] Frikha, B. (2013). Ecomatériel de construction, pilier de la croissance verte en Afrique, Collection Acte de Conférence: 10-12 Juin, 2IE Ouagadougou.

[3] Ntep Gweth, P. (2001). Ressources minérales du Cameroun, Yaoundé.

[4] Tchindjang, M., MbevoFendoung, P., Unusa, H., Voundi, E., Njoumbissi Petcheu, I.C., Saha, F. (2014). Mines contre foret et conservation au Cameroun: Enjeu de l'évaluation environnemental du secteur minier pour le développement durable au Cameroun. Rapport du projet Geoforafri, 38.

[5] Argane. (2015). Traitement des rejets miniers en vue d'une valorisation comme matière première secondaire. 27 eme rencontre annuelle - Canadian Mineral Processors section Nord-Ouest Québécois (CMPNOQ), 16 Septembre 2015, Val D’Or, Canada. (Oral communication).

[6] Toteu, S.F., Van Schmus, R.W., Penaye, J., and Michard, A. (2001). New U-Pb and Sm-Nd data from northcentral Cameroon and its bearing on the pre-Pan-African history of central Africa. Precambrian Research, 108(12): $\quad 45-73$. https://doi.org/10.1016/S03019268(00)00149-2

[7] Gazel, J.G., Gérard, G., Touveron, G. (1947). Carte géologique de reconnaissance à l'échelle du 1/500000, Service des Mines du Cameroun. Notice explicative sur la feuille Batouri-Est.

[8] Vairon, J., Edimo, A., Simeon, Y. et Valada, P. (1986) Protocole d'accord pour la recherchedes minéralisations d'or dans la province aurifère de l'Est (Cameroun). Mission Or Batouri,deuxième et troisième phase. BRGM - Direction des activités minières, Orléans, 251.

[9] Toteu, S.F., Penaye, J., Deloule, E., Van Schmus, W.R., Tchameni, R. (2006). Diachronous evolution of volcanosedimentary basins north of the Congo craton: Insights from $\mathrm{U}-\mathrm{Pb}$ ion microprobe dating of zircons from the Poli, Lom and Yaoundé Groups (Cameroon). Journal of African Earth Sciences, 44(4-5): 428-442. https://doi.org/10.1016/j.jafrearsci.2005.11.011

[10] Kankeu, B., Greiling, R.O., Nzenti, J.P. (2009). PanAfrican strike-slip tectonics in eastern CameroonMagnetic fabrics (AMS) and structure in the Lom basin and its gneissic basement. Precambrian Research, 174(34): https://doi.org/10.1016/j.precamres.2009.08.001

[11] Bertrand, J.M., Barbey, P., Latouche, L., Macaudière, J. (1994). Le socle Précambrien du Cameroun, une revue partielle des travaux récents. Conférence spécialisée, Pangea, (21): 33-41.

[12] Yonta Ngouné, C. (2010). Contexte géologique des indices de talc de la région de Boumnyebel (chaîne panafricaine d'Afrique Centrale, Cameroun). Thèse Doctorat $/ \mathrm{PhD}$ en Sciences de la Terre Université de Yaoundé I et Université Henri Poincaré, Nancy I, 231.

[13] Regnoult, J.M. (1986). Synthèse géologique du Cameroun. Ministère des mines et de l'énergie du Cameroun, Yaoundé, 119.

[14] Leopold, Clarke, Hanshaw, B., Balsley, J.E. (1971). A procedure for evaluating environmental impact. U.S. Geological Survey Circular 645, Washington, D.C.

[15] Martin, F., (1997). Analyse comparative des méthodes de cotation des études d'impact environnemental. Rapport de Recherche, Université du Québec à Montréal, 119.

[16] AFNOR. (1991). Essai de détermination de la masse volumique des sols fins en laboratoire, méthode de la trousse coupante, du moule et de l'immersion dans l'eau, Norme Française, NF P 94-053, Paris.

[17] NF P 54-054. (1991). Essai de détermination de la masse volumique des particules solides des sols, méthode du pycnomètre à eau, AFNOR, Paris.

[18] NF P 94-056. (1996). Essai d'analyse granulométrique des sols, méthode par tamisage à sec après lavage, AFNOR, Paris.

[19] NF P 18-598. (1991). Essai de détermination de l'équivalent de sable, AFNOR, Paris.

[20] Kemajou Noubet, S.W. (2015). Les petites mines d'exploitation de l'or de Bétaré-Oya : types et devenirs des rejets du lavage de graviers. Rapport de Stage, 22.

[21] Nguepjouo, D., Manyacka, E. (2008). Exploitation minière et artisanale dans la province de l'Est Cameroun: cas du département de la Boumba et Ngoko Etat des lieux: constat analyse et recommandation. CED, Yaounde, 67.

[22] Nono, C.A. (2011). Impact de l'exploitation artisanal de l'or sur l'environnement et le développement socioéconomique à Bétaré-Oya / Est Cameroun. Mémoire de master professionnel. Université de Dschang, CRESA FORET BOIS Yaoundé, 119.

[23] Schwartz, B., Hoyle, D., Nguiffo, S. (2012). Tendance émergentes dans les conflits liés à l'utilisation des terres au Cameroun. Chevauchement des permis des ressources naturelles et menaces des airs protégées et les investissements directs étrangers. WWF, CED, RELUFA, Rapport de travail 120p.

[24] Soba Djallo (1989) La série du Lom : étude géologique et géochronologique d'un bassin volcanosédimentaire de la chaine panafricaine à l'Est Cameroun. Thèse de Doctorat d'Etat, Université De Paris VI, 181.

[25] Nodem, V., Bamenjo, J.N. Schwart, Z.B. (2012). Gestion des recettes tirées des ressources naturelles au niveau des collectivités locales au Cameroun. Redevances Foncières et Minières à Yokadouma Est du Cameroun. RELUFA, Rapport de travail, 72.

[26] RELUFA-CED, (2014). Scompagnies minières au Cameroun : Cas du projet du diamant Cameroon and Korea Mining Incorporation, Mobilong, Est Cameroun. Rapport de Travail, 45.

[27] Nguiffo, S., Kenfack, P. (2011). Législation sur les activités extractives, foncières, forestières et environnementales au Cameroun, mise en perspective et gestion des conflits. Rapport de Travail, 74.

[28] Kund and Megevard. (2013). Dynamique de déforestation dans le bassin du Congo Réconcilier la croissance économique et la protection de la foretDocument de travail n4 Exploitation Miniere. Rapport de Travail, 69.

[29] Taha, Y. (2017). Valorisation des rejets miniers dans la fabrication de briques cuites : évaluations technique et environnementale. Thèse de Doctorat en Sciences De L'environnement, Université du Québec en Abitibi Témiscamingue en cotutelle avec l'Université Aadi Ayy Ad, Maroc, 264. https://doi.org/10.13140/RG.2.2.19573.78565

[30] Tchonang, (2014). Plan de valorisation de la sablière artisanal de Toutsang. Mémoire de Master en Science de l'Ingénieur de l'Université de Dschang, 52.

[31] Ngapgue, F., Wouatong, A.S.L., Keyangue Tchouata, 
J.H., Beyala, V.K.K. (2009). Physical characterization of Batié sand (West-Cameroon) and its correction: case study of mount Metchou. JP Journal of Solid and Structures, 3(2): 125-136.

[32] Awona, P.Z. (2012). Étude de comportement du béton à base du sable de la rivière Foulou à Akak. Mémoire de Master en Sciences de l'Ingénieur de l'Université de Dschang, 77.

[33] Batake, E. (2015). Etude sedimentologique et valorisation industrielle des sables de la rivière Nkam. (Secteur Yabassi-Centre). Mémoire de Master en Sciences de la Terre et de l'Univers Spécialité: Géologie des Formations Superficielles, Université De Yaoundé 1Cameroun, 50.

[34] Ngagoum, S. (2017). Etudes pétrographiques et sédimentologies des sables littoraux de Limbe: (sudouest Cameroun) mémoire de Master, 60.

[35] Wentworth, C.K. (1922). A scale of grade and class terms for clastic sediments. The Journal of Geology, 30(5): 377-392. https://doi.org/10.1086/622910

[36] Bedard, P. (2014). Clef d'identification visuelle des grains de sable, version1.0, Cours polymtl.

[37] Dreux, G. (1986). Nouveau Guide du Béton. Paris, éditions Eyrolles. 